Int. J. Speleol. 7 (1975), pp. 65-78.

\title{
Studies on the Niche Separation in Two Carabid Cave Beetles
}

\author{
by \\ Tom MCKINNEY* \\ INTRODUCTION
}

Two closely related species rarely inhabit an area of limited resources because of their ecological similarity (Elton 1946). In this study I looked at aspects of seasonal population change and behavior of Pseudanophthalmus menetriesi and P. pubescens (Carabidae: Trechini) with the purpose of explaining why these two beetles can coexist in the same caves where food input is restricted.

\section{METHODS}

\section{Population Studies}

Population counts were made, when possible, each month from July, 1972, until December, 1973 by manually capturing all the beetles in three one meter square stations in a $13 \mathrm{~m}^{2}$ portion of a rocky stream bed (approximately 20\% of available habitat) and at one $40 \mathrm{~m}^{2}$ stream side bank station (approximately 15\% of available habitat) in Walnut Hill Cave, $3 \mathrm{~km}$ south of Park City, Barren Co. Kentucky. The beetles were identified to species, sex and whether teneral or fully sclerotized and then released at their collection site. The substrate level temperature, stream water level, signs of recent flooding, and the amount of leaf litter at the stations were also noted.

\section{Habitat Studies}

The habitats occupied by Pseudanophthalmus menetriesi and $P$. pubescens were examined in Walnut Hill Cave and Parker Cave $2.8 \mathrm{~km} \mathrm{SW}$ of Park City in Barren Co. Ky. and Hanson Cave $3.9 \mathrm{~km} \mathrm{SW}$ of Hiseville, Barren Co. Ky. Five distinct types of microhabitat in these caves that were commonly occupied by Pseudanophthalmus, were examined: bare clay shelves in Parker Cave (surveyed 5 times between August 1971 and February 1972), an area of heavy litter in Hanson Cave (sampled 3 times from June to September 1973), and three areas in Walnut Hill Cave (examined at least 12 times from November 1972 to December 1973). The

$\overline{\text { *Department }}$ of Biological Sciences, University of Kentucky, Lexington, Kentucky 40506, USA. 
first of these Walnut Hill Cave areas was a rocky stream bed with pockets of litter, the second was a silty stream bed with scattered litter adjacent to the rocky area (both examined twice, in July and August 1973) and the last was a silty stream side bank with scattered litter. The relative abundance of the two beetles and their habitat niche breadth were calculated from these data. These habitats differ in the amount and age of litter present, from no litter on the Parker Cave clay shelves to an almost continuous cover in the Hanson Cave study area. The Walnut Hill Cave rocky stream bed has scattered pockets of litter and both the stream bed and stream side bank silt areas have scattered pieces of litter. The age of the litter also varies, from old (precisely how old is not known) in Hanson Cave to relatively fresh in the Walnut Hill Cave stream bed sites. Litter on the stream side bank station was older than the stream bed litter, but not as old as the Hanson Cave litter. In Walnut Hill Cave, high water replaces some or all of the stream bed litter $9-11$ times per year and replaces the stream side bank litter $2-3$ times per year.

Habitat niche breadth was calculated from the Shannon-Wiener information formula (Ricklefs 1966):

$$
\mathrm{Bi}=\Sigma \mathrm{p}_{\mathrm{ij}} \log \mathrm{p}_{\mathrm{ij}}
$$

here $p_{i j}$ is the proportion of the individuals of species $i$ which is associated with habitat $\mathrm{j} . \mathrm{Bi}=1$ when the proportion of species $\mathrm{i}$ associated with each habitat $\mathrm{j}$ is equal and $\mathrm{Bi}=0$ when all members of species $\mathrm{i}$ are restricted to one habitat.

That beetles of both species are more abundant in litter areas was obvious from preliminary observations in Walnut Hill Cave and in other caves (T.C. Barr personal communication). To examine what happens when fresh cave litter is added to an area with low beetle densities, litter was added to three Parker Cave clay shelf stations, leaving a fourth one bare as a control. Approximately $750 \mathrm{~cm}^{3}$ of litter was placed on stations 1, 2 and 4 on June 28, 1972 and on May 13,1973, $4600 \mathrm{~cm}^{3}$ was added to station $1,7100 \mathrm{~cm}^{3}$ was added to station 2 and $5800 \mathrm{~cm}^{3}$ was added to station 4 , giving approximately equal densities per $\mathrm{m}^{2}$ at each station. Station 3 was left unmodified again to act as a control. The beetle and micro-arthropod populations were surveyed either monthly or bimonthly.

\section{Interspecific Interactions}

Interspecific interaction experiments were carried out for two different lengths of time. Short term experiments were run in storage jars with $1 \mathrm{~cm}$ depth and about $600 \mathrm{~cm}^{2}$ area of uniform cave clay as substrate. Six tests of one hour each were done using one menetriesi and one pubescens of the same sex. In preliminary tests one piece of litter was placed in the jar but, as the beetles did not stop on, under or near it and it occasionally interfered with observations, litter was not used in subsequent tests.

Longterm interspecific interaction experiments were run in 3.8 liter steel framed terraria with $2 \mathrm{~cm}$ of Parker Cave clay covering the bottom which had an area of about $400 \mathrm{~cm}^{2}$. Fresh cave litter, with attendant microarthropods and oligochaetes, 
covered approximately 40 percent of the substrate. Two beetles of each species were placed in each of the five terraria which were checked every three or four days to determine which beetles were still alive. Food (litter) was not renewed.

\section{Digging Experiments}

Digging experiments were run in $11 \mathrm{~cm}$ by $11 \mathrm{~cm}$ by $2.5 \mathrm{~cm}$ extruded plastic sandwich boxes with $1 \mathrm{~cm}$ of cave clay substrate on the bottom. Two hour tests were run with 40 beetles of each species in each test with one beetle per box. At the end of the test period the number of holes dug by all the beetles of each species was counted. The results were analyzed using a $\chi^{2}$ test.

\section{RESULTS}

\section{Population Studies}

Beetle population changes were extrapolated to the $13 \mathrm{~m}^{2}$ study portion of the rocky stream bed area based on the number of beetles at the three one $\mathrm{m}^{2}$ stations. Total surveys of this area were done twice for another purpose and the number of beetles found corresponded well to population estimates done one week later (July 14, actual count 15 menetriesi and 9 pubescens, with an estimate on July 21 of 13 menetriesi and 9 pubescens; August 7, 1973 actual count 22 menetriesi and 15

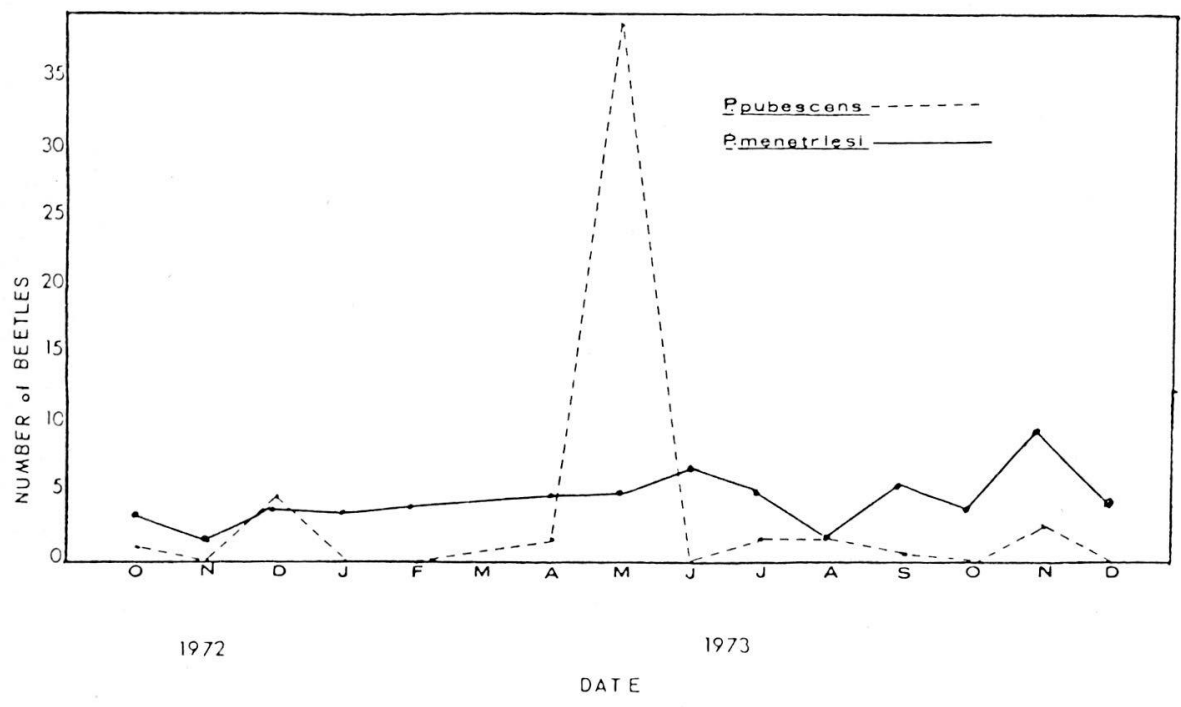

Fig. 1. Population fluctuations in P. menetriesi and P. pubescens in Walnut Hill Cave on the stream bank (for a $39.6 \mathrm{~m}^{2}$ area). 


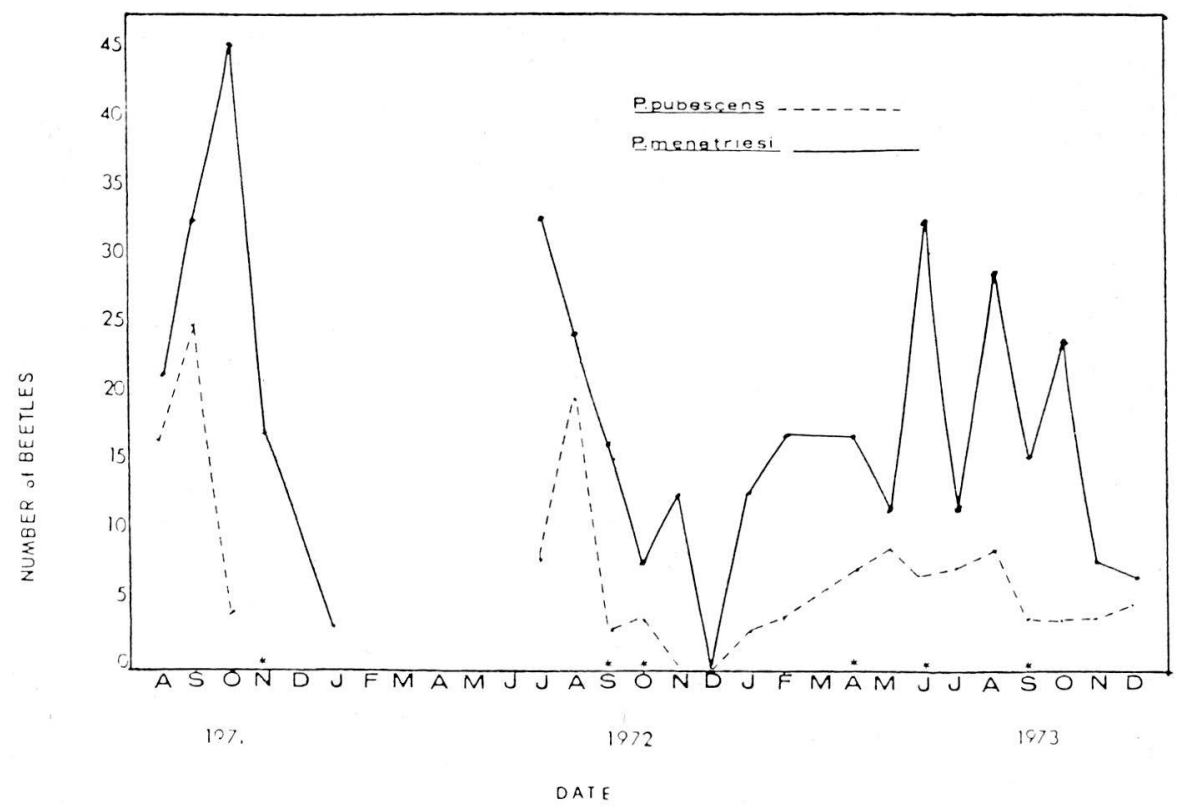

Fig. 2. Population changes in Pseudanophthalmus menetriesi, P. striatus (8) and P. pubescens in Walnut Hill Cave for the years 1971, 1972 and $1973 *$ P. striatus present.

pubescens with August 14 estimates of 29 menetriesi and 9 pubescens). The population estimates for the rocky stream bed area are presented in Figure 1 and Figure 2 represents the actual counts made on the stream bank station. The population densities of both menetriesi and pubescens changed regularly with highest levels reached during the summer and fall and the lowest levels reached during the winter in the stream bed stations, but remaining relatively constant on the stream bank station.

There is a permanent stream in Walnut Hill Cave which flooded to a depth of over 2 meters two or three times a year and to a depth of between 10 and $30 \mathrm{~cm}$ nine or ten times a year during the time this cave was examined. The cave was visited shortly after two different floods, one of 1.6 meters on May 12, 1973 and a less extreme one on December 15, 1972. On December 15, 1972 water covered the stream bed to a depth of $3-10 \mathrm{~cm}$ and no survey could be made, but the stream bank station was examined. Four menestriesi were taken, a not unusual number, but five pubescens were caught, a number twice that seen previously (Figure 1).

On May 12, 1973 the water level was only slightly higher than normal, but there were signs of recent very high water (fresh litter clinging to the cave roof and wall). In the stream bed stations the menetriesi numbers were slightly lower than usual ( 1.3 to 1.0 beetles $/ \mathrm{m}^{2}$ ) whereas the pubescens population increased (from 0.7 to 
1.0 beetles $/ \mathrm{m}^{2}$ ). The stream bank station populations were much higher than usual, but the pubescens increased much more than menetriesi. The menetriesi population was almost twice as dense as usual $\left(0.12\right.$ to .20 beetles $\left./ \mathrm{m}^{2}\right)$ whereas the pubescens population increased from an average of 0.03 to 1.1 beetles $/ \mathrm{m}^{2}$ (Figure 2).

\section{Population Recruitment}

Teneral menetriesi entered the population over a period of 150 days (July 14 to December 15) while teneral pubescens appeared over a much shorter period of time, 68 days (May 12 to July 18) (Table 1). It is important to note that there is almost no overlap in the time of teneral appearance. Some pubescens may appear before May each year and some menetriesi may appear after December since the December - April period has been sampled the least, but there is probably no winter overlap. The lack of summer overlap is real and not due to a lack of observation.

\section{Habitat Studies}

The ratio of pubescens/menetriesi found in each of the microhabitats is presented in Table 2. The proportion of pubescens increases as the amount of litter in the microhabitat increases. The ratio is lowest (relatively more menetriesi) on the bare Parker Cave shelves and the highest (relatively few menetriesi) in the Hanson Cave litter areas, with the three Walnut Hill Cave stations falling in between.

The calculated habitat breadth indicates that menetriesi has a relatively low selectivity $(\mathrm{Bi}=0.74)$ whereas pubescens is more discriminating for habitat choice (bi = 0.43).

The initial addition of litter (June 1972) caused a sharp increase in the number of menetriesi found in the modified Parker Cave shelves and a proportionately greater increase in the pubescens population (compare Table $3 \mathrm{~A}$ and $3 \mathrm{~B}$ ). There was little increase in the visible microarthropod fauna, but large oligochaetes did increase in number, which would suggest an increase in small oligochaetes (Table 4). Other studies (McKinney in preparation) have indicated that pubescens readily utilizes small oligochaetes as food, but menetriesi eats microarthropods before it will attempt to eat oligochaetes and then often the worms are only manipulated and not eaten.

After the initial increase the menetriesi population was relatively stable while the pubescens population declined until a near normal density was reached after 7 months. The pubescens/menetriesi ratio had dropped below that of the control survey period by February 25, 1973. There was little decomposition of litter over this period of time. The control station (Table 3B) showed no increase in beetle density, and actually lacked pubescens most of the time.

The change in Pseudanophthalmus populations was greater on these same shelves after the addition of ten times as much leaf litter in May 1973 (Table 3A). With the addition of this large amount of litter the number of beetles and the ratio of pubescens/menetriesi went up, with pubescens again increasing proportionately 
more than did menetriesi. The ratio obtained was actually higher than for all of the natural microhabitats examined except the Hanson Cave litter areas. The microarthropods and large oligocheates (and probably small oligochaetes) also increased dramatically (Table 4). As after the first modification, the numbers of menetriesi remained relatively constant, at least through October 1973, while the pubescens population fell below the menetriesi population by October. There was only a slight

Table 1. Date of appearance and per cent light teneral Pseudanophthalmus in Walnut Hill Cave, Parker Cave and Hanson Cave. P. menetriesi appears over a longer period of time than $P$. pubescens and there is little temporal overlap between the two species with pubescens showing spring and menetriesi showing summer-fall recruitment.

P. menetriesi

Cave

Walnut Hill Cave

Parker Cave

Parker Cave

Walnut Hill Cave

Hanson Cave

Walnut Hill Cave

Walnut Hill Cave

Parker Cave

Walnut Hill Cave

Walnut Hill Cave

Walnut Hill Cave

Parker Cave

Walnut Hill Cave
Date

$7 / 14 / 73$
$8 / 18 / 72$
$9 / 19 / 71$
$9 / 16 / 72$
$9 / 27 / 73$
$9 / 28 / 73$
$10 / 23 / 71$
$10 / 24 / 71$
$10 / 19 / 73$
$11 / 17 / 73$
$12 / 15 / 72$
$12 / 14 / 73$
$12 / 15 / 73$

$\overline{\mathrm{x}}=13.9$
Percent

teneral

3.8

17.1

5.0

9.2

14.3

10.0

15.4

12.5

20.0

16.6

12.5

11.1

33.3
Number of tenerals

1 of 26

3 of 18

1 of 20

1 of 12

1 of 7

1 of 10

2 of 13

1 of 8

2 of 10

2 of 12

1 of 8

1 of 9

2 of 6

\section{P. pubescens}

Walnut Hill Cave

$5 / 12 / 72$

2 of 13

Walnut Hill Cave

$6 / 26 / 73$

33.3

1 of 3

Hanson Cave

$6 / 26 / 73$

13.8

5 of 36

Parker Cave

$6 / 30 / 73$

1 of 14

Parker Cave

$7 / 12 / 72$

15.3

2 of 13

Hanson Cave 
Table 2. Pseudanophthalmus pubescens/P. menetriesi ratios in Walnut Hill Cave, Parker Cave, and Hanson Cave show that $P$. pubescens/P. menetriesi ratio increases with increasing litter (caves arranged in increasing order of their litter content).

Sample site

$$
\begin{aligned}
& \text { P. menetriesi P. pubescens Ratio } \\
& \text { number number/ number number/ \#P.p./ } \\
& \mathrm{m}^{2} \quad \mathrm{~m}^{2} \quad \text { \#P.m. }
\end{aligned}
$$

$\begin{array}{lccccc}\begin{array}{l}\text { Parker Cave shelves } \\ \text { Walnut Hill Cave } \\ \text { stream side bank }\end{array} & 30 & 1.1 & 5 & 0.19 & 0.17 \\ \begin{array}{c}\text { Walnut Hill Cave } \\ \text { stream bed silt }\end{array} & 27 & 0.12 & 16 & 0.03 & 0.29 \\ \begin{array}{c}\text { Walnut Hill Cave } \\ \text { stream bed rocks }\end{array} & 34 & 1.1 & 6 & 0.30 & 0.22 \\ \begin{array}{c}\text { Hanson Cave } \\ \text { stream bed litter }\end{array} & 28 & 1.1 & 93 & 0.95 & 0.61\end{array}$

Table 3A. Pseudanophthalmus pubescens (P.p.) and P. menetriesi (P.m.) numbers and densities, and the P.p./P.m. ratios which show an increase with litter addition (total area $=5.13 \mathrm{~m}^{2}$ ).

$\begin{array}{lccccc} & \text { P.p. } & \text { P.p. } / \mathrm{m}^{2} & \text { P.m. } & \text { P.m. } / \mathrm{m}^{2} & \text { \#P.p./\#P.m. }\end{array}$

Modification 1 (light litter)

\begin{tabular}{rrrrrl}
$6 / 18 / 72$ & \multicolumn{7}{l}{ Litter placed on shelves } & & & \\
$7 / 12 / 72$ & 19 & 3.4 & 11 & 2.0 & 0.58 \\
$8 / 18 / 72$ & 8 & 1.4 & 5 & 0.9 & 0.51 \\
$9 / 17 / 72$ & 9 & 1.6 & 4 & 0.7 & 0.44 \\
$10 / 22 / 72$ & 7 & 1.3 & 3 & 0.5 & 0.43 \\
$2 / 25 / 73$ & 8 & 1.4 & 1 & 0.2 & 0.13
\end{tabular}

\begin{tabular}{|c|c|c|c|c|c|}
\hline $5 / 13 / 73$ & \multicolumn{5}{|c|}{ Litter placed on shelves } \\
\hline $6 / 30 / 73$ & 14 & 2.5 & 19 & 3.4 & 1.35 \\
\hline $7 / 30 / 73$ & 13 & 1.3 & 14 & 2.5 & 1.08 \\
\hline $8 / 13 / 73$ & 12 & 2.2 & 19 & 3.4 & 1.58 \\
\hline $10 / 18 / 73$ & 12 & 2.2 & 7 & 1.3 & 0.58 \\
\hline $12 / 14 / 73$ & 8 & 1.4 & 4 & 0.7 & 0.50 \\
\hline
\end{tabular}

* based on five visits from August 1971 until February 1972.

Modification 2 (heavy litter) 
Table 3B. Pseudanophthalmus pubescens and $P$. menetriesi numbers, density and the P.p./P.m. ratio for the unmodified control station $\left(\right.$ area $\left.=3.75 \mathrm{~m}^{2}\right)$ showing population changes during the periods of modification of other stations.

$$
\begin{array}{llll}
\text { P.p. } & \text { P.p. } / \mathrm{m}^{2} & \text { P.m. } & \text { P.m. } / \mathrm{m}^{2} \quad \text { \#P.p. } / \# \text { P.m. }
\end{array}
$$

Time of modification 1

$\begin{array}{rrrrrr}7 / 12 / 72 & 3 & 0.9 & 2 & 0.5 & 0.66 \\ 8 / 18 / 72 & 0 & - & 0 & - & - \\ 9 / 17 / 72 & 3 & 0.9 & 0 & - & - \\ 10 / 22 / 72 & 2 & 0.5 & 0 & - & - \\ 2 / 25 / 73 & 0 & - & 0 & - & -\end{array}$

Time of modification 2

$\begin{array}{rrrrrr}6 / 30 / 73 & 3 & 0.9 & 1 & 0.5 & 0.33 \\ 7 / 19 / 73 & 1 & 0.3 & 0 & - & - \\ 8 / 13 / 73 & 2 & 0.5 & 1 & 0.3 & 0.50 \\ 10 / 18 / 73 & 1 & 0.3 & 0 & - & - \\ 12 / 14 / 73 & 1 & 0.3 & 0 & - & -\end{array}$

change in prey species numbers from May 1973 until December 1973, but small oligochaetes could not be surveyed and could possibly have declined.

The number of beetles seen at the control station increased somewhat during 1973 (Table 3B). This beetle increase is possibly due to an overflow from the modified stations since the microarthropod fauna at this control station did not change (Table 4).

\section{INTERSPECIFIC INTERACTIONS}

In short term experiments pubescens clearly showed that it is more aggressive than menetriesi, with 30 aggressive acts committed vs. 12 for menetriesi in six hours of observation (12 individuals in 6 pairs for 1 hour per pair). These aggressive encounters started when two beetles made contact with each other and ended when one, the loser, ran from the victor. In all cases the beetle that initiated the aggression after contact was the dominant beetle in that encounter. The losing beetle always ran away from the winner who usually remained in place 2 - 3 seconds and then resumed its normal walking pattern. Occasionally the winner chased the losing beetle $2-3 \mathrm{~cm}$ before it resumed its normal behavior. On 14 occasions there were neutral encounters when the beetles touched each other but did not change their behavior.

No intraspecific interaction experiments were run in storage jars, but a few intraspecific interactions were observed in conjunction with other experiments run 
on the two species. The interactions were similar, however much less common (2 aggressive interactions initiated in 10 hours by menetriesi and 4 aggressive interactions initiated in 10 hours by pubescens using 5 pairs for each species).

Longterm interaction tests also showed that pubescens was the more aggressive of the two species. The first beetle eliminated from 3 of the 5 terraria was a menetriesi and the survivor of 4 of the 5 experiments was a pubescens. In the 4 tests where menetriesi was eliminated the last menetriesi disappeared 125, 201, 119 and 129 days after the start of the test. This is well within the length of life of this species as controls lived for an average of 219 days and the menetriesi that ended up as the survivor was still alive after 165 days.

\section{DIGGING EXPERIMENTS}

$P$. menetriesi dug significantly fewer holes than $P$. pubescens did during the two hour test periods ( 9 vs $70, \chi^{2}=4.72, \mathrm{p}>.005$ ). Many of the holes dug by both species were in irregularities in the clay along the edge of the test chamber.

\section{DISCUSSION}

The population lows in the stream bed stations in Walnut Hill Cave were probably caused by cold temperatures (this cave is relatively short and there was a $5.6 \mathrm{C}$ range in temperature recorded during the period of study) and a cold, drying wind that blew into the cave during the winter. This wind current formed a layer approximately $0.6 \mathrm{~m}$ deep next to the floor and only minimally affected the stream bank station. On "warm" winter days when there was little wind, and warmer temperatures, the stream bed populations increased in size (see Jan. 1972, Figure 2). Whether the beetles hid in cracks or moved to deeper and inaccessible passages of the cave is unknown.

Deike (1967) felt that there is a large stream passage inaccessible to man, $16 \mathrm{~m}$ below the end of Walnut Hill Cave. The rapid increase in the visible population size of pubescens after heavy floods, even during the winter, suggests that pubescens has large populations, in this and other lower level cave passages, that are active at all times and can be forced up to higher levels by floods. The visible populations of menetriesi increase less than pubescens after floods which implies that the lower level pubescens populations are larger relative to the accessible menetriesi populations.

It is tempting to speculate that because of the differences in the time of appearance of tenerals in menetriesi and pubescens populations (Table 1) the breeding times are also different. With larva of the two species at different stages of development and sizes, potential competition between the larva could be lessened. Most epigean carabids are either summer or fall breeders (Viljm, et al. 1961) and species of both types can be found in any one geographical area. Usually species of one genus reproduce at the same time of the year at one location (Gilbert 1956) but in 
Table 4. Parker Cave station organisms by month and station illustrating change in organisms with the addition of litter: $+=5-13,++=13-20,+++=20+$ (Area experimental stations $=5.1 \mathrm{~m}^{2}$, area control station $\left.=3.8 \mathrm{~m}^{2}\right)$

Date

Station

$8 / 18 / 71$

Control station

Experimental station

$9 / 19 / 71$

Control station

Experimental station

10/24/71

Control station

Experimental station 1

11/27/71

Control station $\quad 0$

Experimental station 1

1/23/72

Control station 3

Experimental station +

$6 / 28 / 72$ First addition of litter 7/12/72

Control station

Experimental station

$8 / 18 / 72$

Control station

Experimental station + 9/17/72

Control station +

Experimental station $\quad++$
Organism

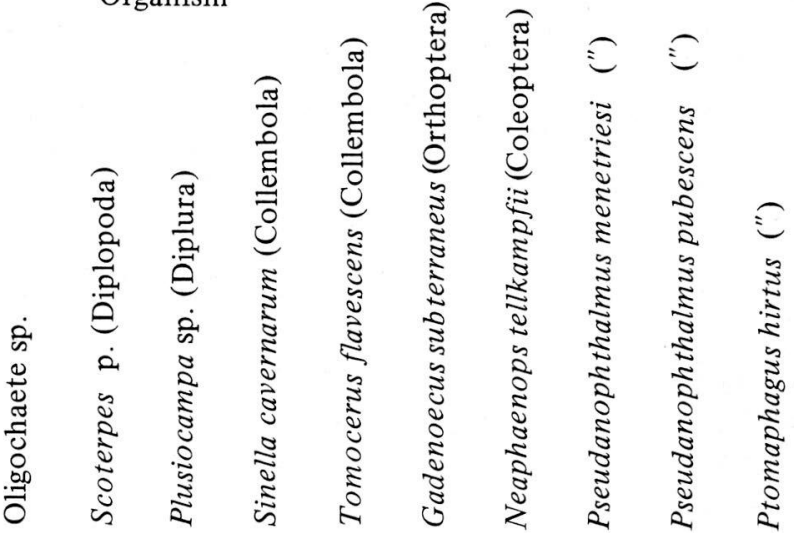


Date

Station

$10 / 22 / 72$

Control station

Experimental station ++

$5 / 13 / 72$ Second addition of litter $6 / 30 / 72$

Control station

Organism

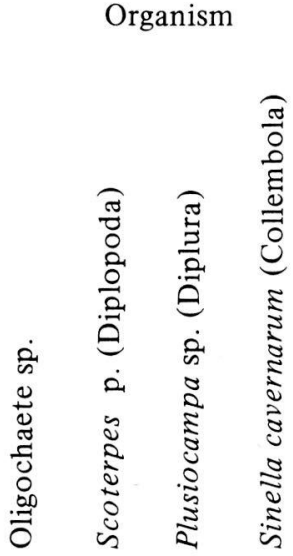

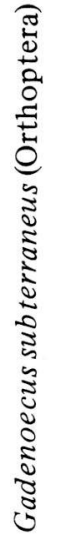

$\begin{array}{lllll}+ & 0 & 0 & 0 & 0 \\ ++ & 8 & 7 & 3 & 1\end{array}$

$\begin{array}{lllllllllll}\text { Experimental station } & ++ & 2 & 5 & 6 & 9 & +++ & 6 & 14 & 19 & 4\end{array}$ $7 / 19 / 73$

$\begin{array}{lllllllllll}\text { Control station } & 0 & 0 & 0 & 0 & 0 & 0 & 0 & 0 & 0 & 0\end{array}$

$\begin{array}{lllllllllll}\text { Experimental station } & +++ & 2 & 6 & ++ & +++ & +++ & 7 & 13 & 14 & 2\end{array}$ $8 / 13 / 73$

$\begin{array}{lllllllllll}\text { Control station } & 0 & 0 & 0 & 0 & 0 & 0 & 0 & 0 & 0 & 0\end{array}$

$\begin{array}{llllllllllll}\text { Experimental station } & +++ & 1 & 3 & ++ & ++ & ++ & 12 & 12 & 19 & 6\end{array}$ $10 / 18 / 73$

Experimental station +++1

$\begin{array}{lllllll}0 & 0 & 0 & 0 & 0 & 0 & 0\end{array}$ $12 / 15 / 73$

Control station $\quad 0 \quad 0$

Experimental station ++1

$\begin{array}{llllll}0 & 0 & + & 0 & 0 & 0\end{array}$

++ $11+++\quad 0 \quad 8 \quad 4 \quad 6$ 
these congeneric beetles it would be advantageous to separate breeding times. The low percentage of tenerals encountered in these populations suggests that these Pseudanphthalmus live for more than one year, unlike most other carabids (Murdoch 1966) and possibly breed more than once (Gilbert 1956).

During the time of appearance of tenerals in the menetriesi an average of $13.9 \%$ of the population is made up of light-colored tenerals for 5 months which means that approximately $70 \%$ of the population is recruited into the population in one year and the population turns over every $11 / 3$ years. Similarly an average of $10.7 \%$ of the pubescens population are light-colored tenerals for 3 months and so $33 \%$ of the population is recruited each year, which means that it takes 3 years for the pubescens population to turn over. These calculations are based on two assumptions and subject to one reservation. The first assumption is that there was no overlap between the teneral individuals seen from one visit to the next. This is really no problem since only light tenerals were counted; those that were almost fully sclerotized were noted, but not used to figure the percentage of tenerals in the population. The second assumption is that the number of tenerals approximates the number of adult beetles dying in the same period of time. This cannot be proven from the information available, but there is no reason to doubt that on average this is what happens. The big problem lies in the fact that the pubescens population seems to be centered, in Walnut Hill Cave at least, in an area that cannot be surveyed and therefore the percent teneral pubescens may really be higher than indicated by the sampling done in the acessible portion of the cave.

In the five different microhabitats examined in Parker Cave, Walnut Hill Cave and Hanson Cave the areas with the greatest amount of litter had the largest Pseudanophthalmus populations and the proportion of pubescens was the highest. $P$. menetriesi was relatively much more abundant than pubescens in the areas with low litter content. It would seem that menetriesi is better able to utilize the resources available in open and scattered litter areas than is pubescens. This may be due to the fact that pubescens prefers to eat small litter dwelling oligochaetes over the microarthropods that are found in open areas and that menetriesi is more efficient at catching these small collembola and mites (McKinney in preparation).

Microarthropods and other potential food items in the cave litter added to the litter-free shelves in Parker Cave in the habitat modification experiments allowed both beetle populations to increase by immigration. The litter added in July 1972, was scattered to a greater extent than in the Walnut Hill Cave stream bed areas and could not indefinitely support some prey species and the high beetle populations. The larger amounts of litter added im May 1973 allowed prey species to reach higher levels so higher beetle populations were supported for longer periods of time. There was a slight decrease in most prey species numbers from May 1973 until December 1973, but small oligochaetes could not be surveyed and possibly could have become less common than other organisms which could have caused a disproportionate decrease in the pubescens population.

The ability of $P$. menetriesi to maintain relatively large populations in both litter and nonlitter areas also suggests that this species is either an unspecialized predator and can take advantage of prey species that maintain populations outside of the 
litter and that pubescens does not utilize these organisms, or that menetriesi is more efficient at catching prey in open areas than pubescens, or both. The fact that pubescens digs significantly more holes than menetriesi also suggests differences exist in the food preference for the two species.

Both the short and the longterm interspecific interaction experiments indicate that pubescens is more aggressive than menetriesi when the two species encounter each other. Even if this interference is small, it may be important in lessening competition for scarce resources. Because there are more collembola/unit volume of litter in Hanson Cave than Walnut Hill Cave (McKinney in preparation) menetriesi would be expected to have higher populations in Hanson Cave than Walnut Hill Cave, but it does not. Competitive interference (Cameron 1971, Culver 1970) in Hanson Cave caused by the large pubescens population may keep the number of menetriesi lower than could be supported by the available food supply.

\section{CONCLUSION}

Potential competition in the closely related beetles could be lessened by: 1) the differences in the timing of larval development, 2) by differences in habitat niche breadth, 3) by differences in food preference, and 4) by competitive interference of $P$. pubescens with $P$. menetriesi when pubescens populations are large.

\section{ACKNOWLEDGMENTS}

I want to thank Dr. T.C. Barr for his help and guidance during this study and Dr. T.L. Poulson who gave much appreciated advice on the project and on the preparation of this paper. Dr. D.C. Culver and Mr. Thomas Kane offered valuable comments of an early draft of this paper.

\section{SUMMARY}

Population, habitat and behavioral studies carried out on Pseudanophthalmus menetriesi and $P$. pubescens in the south central Kentucky karst area are described and discussed. Differences which exist in the timing of population recruitment, habitat preference, habitat niche breadth and in the degree of agression are all important in lessening competition between these two species.

\section{RESUME}

L'auteur décrit et discute des études menées dans la zone karstique du Centre-Sud du Kentucky, sur la population, l'habitat et le comportement de Pseudanophthalmus menetriesi et $P$. pubescens. Les différences qui existent entre les durées de 
renouvellement de la population, la taille des biotopes et le taux d'agressivité entre les espèces, sont d'autant plus importantes qu'elles diminuent la compétitivité entre les deux pespèces.

\section{REFERENCES}

Cameron, G.N. 1971. Niche overlap and competition in woodrats. Mammalogy, 52: 288-296.

Culver, D. C. 1970. Analysis of simple cave communities: Niche separation and species packing. Ecology 51: 952-958.

Deike, G. H. 1967. The development of caves in the Mammoth Cave region. Unpublished PhD dissertation. Pennsylvania State University $235 \mathrm{pp}$.

Elton, C. S. 1946. Competition and structure of ecological communities. Animal Ecology, 15: 54-68.

Gilbert, O. 1956. Natural History of four species of Calathus (Coleoptera:Carabidae) living in sand dunes in Anglesey, North Wales. Oikos, 7: 22-47.

Murdoch, W. W. 1966. Aspects of the population dynamics of some marsh Carabidae. Animal Ecology, 35: 127-156.

Ricklefs, R. E. 1966. The temporal component of diversity among species of birds. Evolution, 20: $235-242$.

Rivard, I. 1964. Observations on the breeding periods of some ground beetles (Coleoptera:Carabidae) in eastern Ontario. Can. J. Zool., 42: 1081-1084.

Vlijm, L., L. Hartsuijker, and C. J. J. Richter. 1961. Ecological studies on carabid beetles. I Calathus melanocephalus (Linn.). Arch. Neerl. Zool., 14: 410-422. 